\title{
Clinical and immunopathological studies of pars planitis in a family
}

\author{
RICHARD P WETZIG,' CHI-CHAO CHAN,' ROBERT B NUSSENBLATT,' \\ ALAN G PALESTINE,' DAVID O MAZUR, ${ }^{2}$ AND KAMAL K MITTAL ${ }^{3}$
}

From the 'National Eye Institute, National Institutes of Health, Bethesda, the ${ }^{2}$ Naval Hospital, Naval Medical Command, Bethesda, and the ${ }^{3}$ Office of Biologics Research and Review, CDB, FDA, Bethesda, Maryland, USA

SUMmaRY We examined a family in which two brothers with identical HLA typing have pars planitis with snowbanking. Immunopathological studies of one of their eyes showed that in the area of snowbanking over the pars plana there was mild to moderate inflammatory cell infiltration, consisting of mostly Pan T (Leu 4+) lymphocytes. The ratio of T helper/inducer to T suppressor/ cytotoxic cells was approximately 10:1. Few macrophages $(\mathrm{OKM} 1+)$ were identified. Very few $B$ cells and no NK cells were observed. Some retinal vessels had a perivascular infiltration consisting of mostly T lymphocytes. Most of the inflammatory cells bore class II antigens (HLA-DR+), while $\mathrm{T}$ cells bore few IL-2 receptors (anti-TAC + ). The snowbank consisted mainly of glial elements (GFAP+) and basement membrane components (type IV collagen and laminin) with the predominant cell the Müller cell (Mü+). A site of inflammation at the iris-ciliary body junction also stained for B cells (Leu 14+). These findings suggest that the snowbank could be formed by the glial elements of the peripheral retina. The chronic inflammation in pars planitis appears to consist of helper $\mathrm{T}$ cells, both in the pars plana, and the retinal vasculature.

Pars planitis is an inflammation of the ciliary body, vitreous base, and peripheral retina.' First called peripheral uveitis, ${ }^{12}$ it has also been called chronic cyclitis $^{3}$ in addition to pars planitis. ${ }^{4}$ Clinically pars planitis is characterised by the formation of snowbanking, which is seen as a massive exudation over the ora serrata. Macular oedema and cataracts often decrease vision. Less commonly, retinal detachments, neovascularisation, and intraocular haemorrhage occur. The anterior segment of the eye usually remains quiet. Children and young adults are most often affected. Treatment may include cryotherapy, ${ }^{5}$ depot steroid injection, ${ }^{6}$ systemic immunosuppression with steroids and cytotoxic agents, ${ }^{7}$ and systemic treatment with cyclosporine A. ${ }^{8}$ It must be distinguished from sarcoid uveitis and Toxocara canis infection.

Previous histopathological studies of pars planitis have shown evidence of a retinal vasculitis, cyclitis," and choroiditis. ${ }^{310}$ Fibroglial proliferation in the area

Correspondence to Richard P Wetzig, MD, National Eye Institute, National Institutes of Health, Bldg 10, Room 10N222, Bethesda, MD 20892, USA. of the snowbank has been described." The mechanisms that lead to the production of the snowbanks are not known.

Although generally not thought to be familial, there have been reports of siblings having the disease. ${ }^{312}{ }^{13}$ No genetic linkage to HLA loci or other genetic markers have been established, however.

This paper discusses our immunohistochemical study of an eye from a patient with pars planitis. The brother, who also has pars planitis, the patient, and their mother were HLA typed.

\section{Case report}

The patient was a 16-year-old white male with a three-year history of pars planitis in both eyes. The left eye had been more involved than the right. In that eye he had developed band keratopathy, vitreous reaction, snowbanking, traction retinal detachments, and vitreous haemorrhages. He underwent lensectomy, vitrectomy, and retinal detachment repair in the left eye. The patient had recurrent hyphaemas, vitreous haemorrhage, and rubeosis in 
that eye, leading to no light perception and pain. The eye was enucleated eight months postoperatively.

The patient was started on cyclosporine $\mathrm{A}$ for his remaining eye at a dose of $9.5 \mathrm{mg} / \mathrm{kg} / \mathrm{day}$. Vision before treatment was 20/100 and after three months of treatment was 20/63, with improvement in his chronic inflammation.

The patient's brother also had bilateral pars planitis with snowbanking. The mother's eyes were normal. Although the father was not available for HLA typing, the patient, his brother, and their mother were typed, with the following results: patient, A2, A3; B7, B57; DR2, DR7; brother, A2, A3; B7, B57; DR2, DR7; mother, A2, A32; B7, B27; Cw2; DR2, DR7.

The patient's lymphocytes were tested, and did not respond to S-antigen. In addition, he had a normal peripheral T-cell count.

\section{CONTROL EYE}

A second eye without pars planitis was studied as a control. The patient was 37 years old and had a blind painful eye. There had been a knife injury at age 2 . At age 26 the patient had a corneal graft. There was a retinal detachment one year later that was repaired. The detachment repair failed. Prior to enucleation there were band keratopathy and glaucoma.

\section{Materials and methods}

The enucleated eyes were snap frozen and embedded in optimal cutting temperature compound (OCT). Frozen $4 \mu \mathrm{m}$ sections were prepared and stored at $4^{\circ} \mathrm{C}$ for 48 hours prior to staining. Mouse-antihuman monoclonal antibodies from Becton Dickinson (Sunnyvale, CA) were used to identify various lymphocyte subpopulations and other antigenic determinants. Monoclonal antibodies detecting determinants on bone marrow monocytes were OKM1. Antibodies specific for T cells were Leu 2a, Leu 3a, Leu 4, Leu 8 and Leu 15. Leu 7 was specific for natural killer (NK) cells. Leu 14 was specific for B-cells. In addition antibodies against the major histocompatibility IL-2 complex (MHC) class II antigen (HLA-DR), the II 2 receptor (anti-TAC), retinal $S$ antigen (anti-S), Müller cell components (Mü), and glial fibrillary acid protein (GFAP) were used. Immunohistochemistry studies were performed by the avidin-biotin-peroxidase (ABC) method. ${ }^{14}$ The sections were fixed in acetone for 5 minutes, transferred to Tris-buffered saline, $0.05 \mathrm{M}$, at a $\mathrm{pH}$ of $7 \cdot 6$, and then immersed in $10 \%$ normal horse serum in buffer for 5 minutes. The primary monoclonal antibodies were used at a concentration of 1 to $2 \mu \mathrm{g} / \mathrm{ml}$. After incubation in a moist chamber at room temperature for one hour the slides were washed in Tris- buffered saline, then the secondary antibody, biotinconjugated horse antimouse IgG, 1:200, was layered on the slides. The slides were again incubated in a moist chamber at room temperature for another hour. After washing in Tris-buffered saline, ABC 1:100 was applied for 45 minutes. The slides were washed again in Tris-buffered saline, and incubated in diaminobenzide- $8 \%$ nickel sulphate and $3 \% \mathrm{H}_{2} \mathrm{O}_{2}$ solution. The slides were counterstained with methyl green ( $1 \%$ in methanol), dehydrated, and cleared as in routine processing.

Immunofluorescence staining was also performed. Air dried frozen sections were washed twice in phosphate buffered saline (PBS) (pH 7.4). The slides were incubated for 30 minutes at room temperature in a moist chamber with the primary antibodies (against collagen type I, collagen type III, collagen type IV, and laminin). They were then washed three times in PBS. Then the slides were incubated with fluorescein labelled antibody against the primary antibody IgG for 30 minutes in a moist chamber at room temperature. The slides were then washed three times in PBS, mounted with Gelvatol, and covered with glass coverslips.

\section{Results}

Macroscopic. The globe measured $22 \times 20 \times 23 \mathrm{~mm}$. A $360^{\circ}$ scleral buckle was present at the anterior sclera. The cornea was opaque. The anterior chamber was not visible. The eye was transluscent. The globe was opened horizontally. A total funnel-shaped retinal detachment was seen.

Microscopic. The corneal stroma was compressed. Descemet's membrane was intact. The corneal endothelium was markedly attenuated. The anterior chamber was shallow and filled with blood. The angle structure was completely closed by synechiae. A few chronic inflammatory cells (plasma cells and lymphocytes) could be seen at the angle. The anterior iris tissue was covered partially by Descemet's membrane and a thin layer of fibrovascular tissue. Scattered chronic inflammatory cells were seen in the iris stroma. The ciliary body showed mild oedema, atrophy, and chronic inflammatory cell infiltration. The lens was absent. A thick layer of fibrous-like tissue (snowbanking) was present at the base of the ciliary body and pars plana (Fig. 1A). The pars plana showed moderate to marked oedematous change. There was mild to moderate lymphocytic cell infiltration in the pars plana region. The retina was totally detached in a funnel-shaped configuration. Its structure was completely disorganised and showed gliosis. There was one area of iron staining in the retina, and in another area there were a few epithelial cells which may represent lens epithelial cells or retinal 

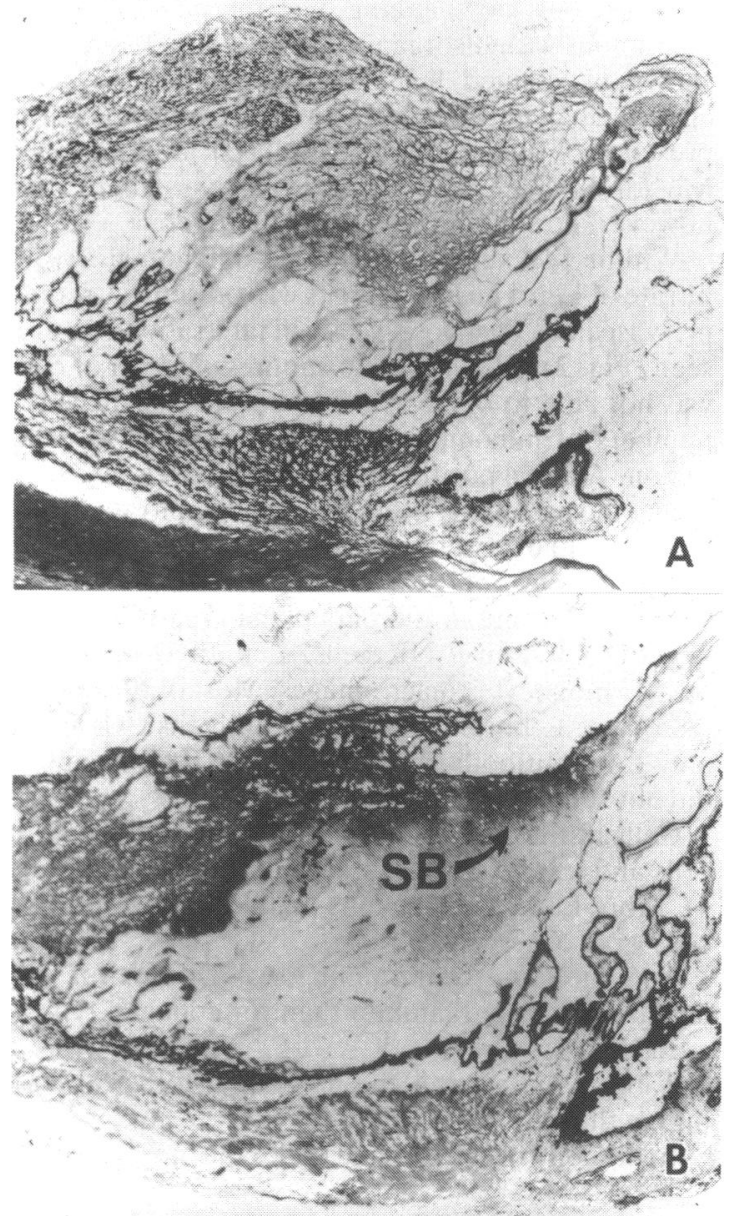

Fig. 1A: The snowbanking was continuous with an area of disorganised glial tissue continuous with the retina (haematoxylin and eosin). B: The area of snowbanking over the pars plana stained heavily for GFAP (arrow), confirming the presence of glial elements.

pigment epithelium (RPE) metaplasia. The vitreous cavity was compressed by the detached retina and contained a small amount of old blood. A small amount of proteinacious material was seen in the subretinal space. The RPE showed mild to moderate irregularity with focal hyperplasia and hypertrophic changes, more peripherally. The choroid was relatively intact except at the peripheral region, where a scattered lymphocytic infiltration was identified. A large scleral buckle was seen near the pars plana region on one side and peripheral retina on the other side. Very mild chronic inflammation was seen around the buckle. The posterior sclera was mildly thickened. The optic nerve was atrophic with loss of neural substance and gliotic changes.

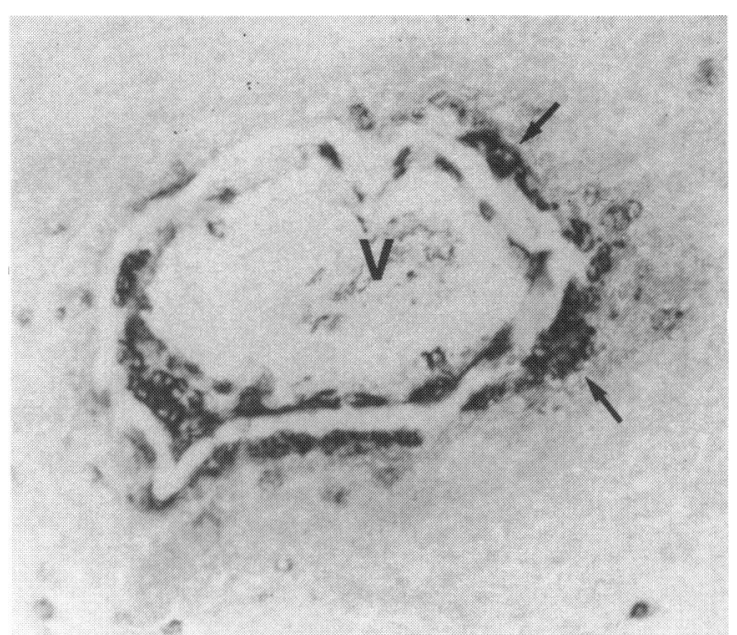

Fig. 2 A retinal vessel had a perivascular Leu 4 positive $T$ cell infiltrate (arrows).

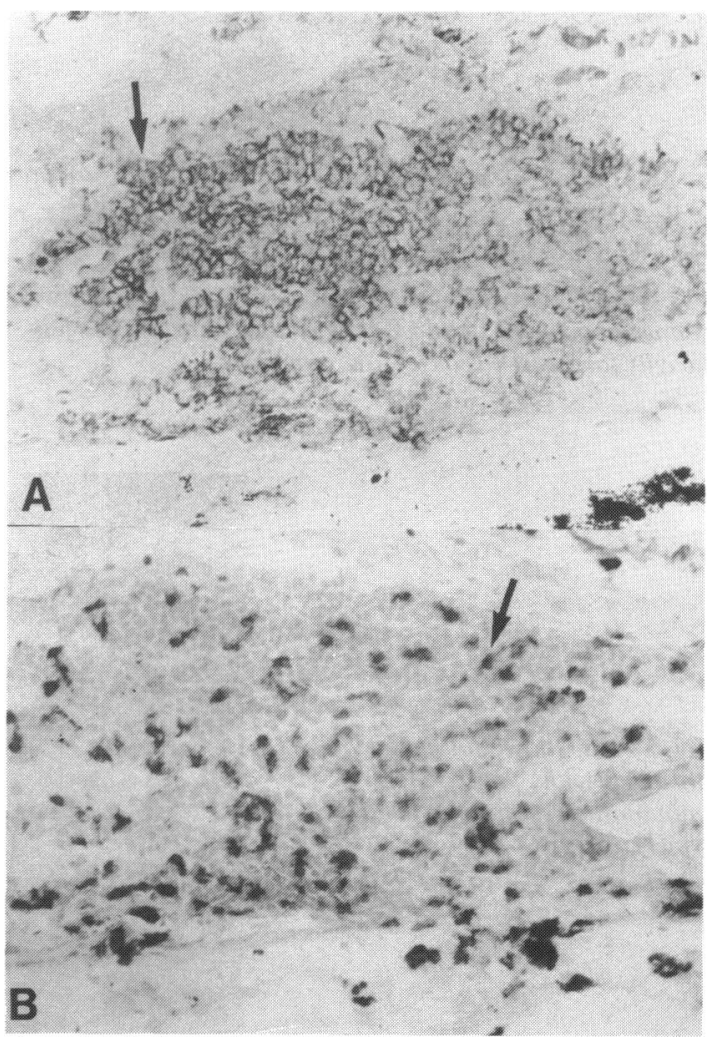

Fig. 3 The Tcell infiltrate beneath the pars plana was predominantly Leu 8 positive Thelper cell (arrow, panel A) as opposed to Leu 2 positive suppressor/cytotoxic cell (arrow, panel $B$ ). 


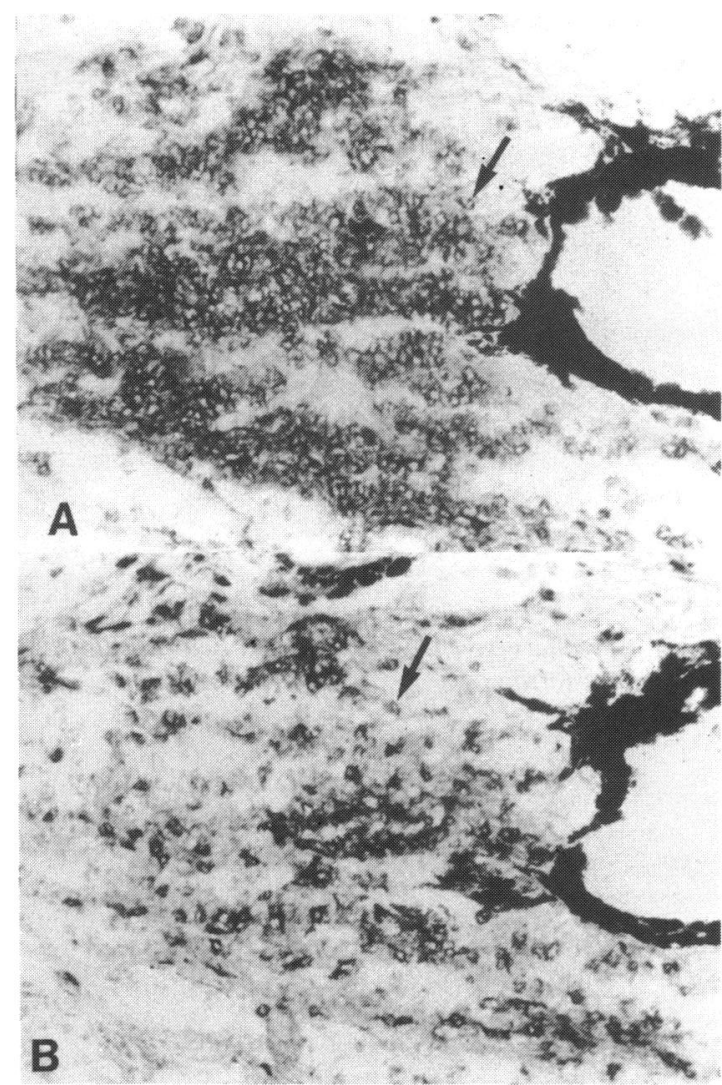

Fig. 4 An area at the junction of the iris and ciliary body stained heavily for Leu 14 B cells (arrow, panel A) and less heavily for Leu 4 T cells (arrow, panel B).
The immunopathological studies showed that the large area of snowbanking over the pars plana was continuous with disorganised retinal glial tissue. The snowbank stained heavily with antibody directed against glial fibrillary acid protein, confirming the presence of glial elements (Fig. 1B). Staining with Mü for Müller cells was also positive. There was, however, no staining for retinal $\mathrm{S}$ antigen.

Within the snowbank a mild inflammatory infiltrate of Leu 4 positive T cells was present. A retinal perivascular Leu 4 positive $\mathrm{T}$ cell infiltration was also seen (Fig. 2). The helper to suppressor ratio of cells was not able to be determined because of the small numbers of inflammatory cells in the peri-vascular region. A Leu 4 positive $T$ cell infiltrate was also seen within the pars plana itself. The $T$ cell infiltrate within the pars plana was predominantly Leu $3 \mathrm{a}^{+} / 8^{+} \mathrm{T}$ helper cell, as opposed to Leu 2a T suppressor cell (Fig. 3). Staining in the pars plana area was largely negative for Leu 7 NK cells, Leu 14 B cells, and OKM1 monocytes/macrophages. Most of the inflammatory cells bore class II, DR antigens, while the anti-TAC antibody directed against IL-2 receptors did not stain cells in most areas.

Cells at the iris root stained heavily for Leu 14 B cells and less heavily for Leu 4 positive $T$ cells (Fig. 4). More Leu 3a helper cells than Leu 2a suppressor cells were observed.

Immunofluorescent staining was greater for collagen type IV and laminin than for collagen types I and III (Fig. 5).

Table 1 summarises the immunohistological findings in the patient's eye.

In the control eye the area under the pars plana was
Fig. 5 The snowbank stained positively with immunofluorescence for collagen type IV (arrow).

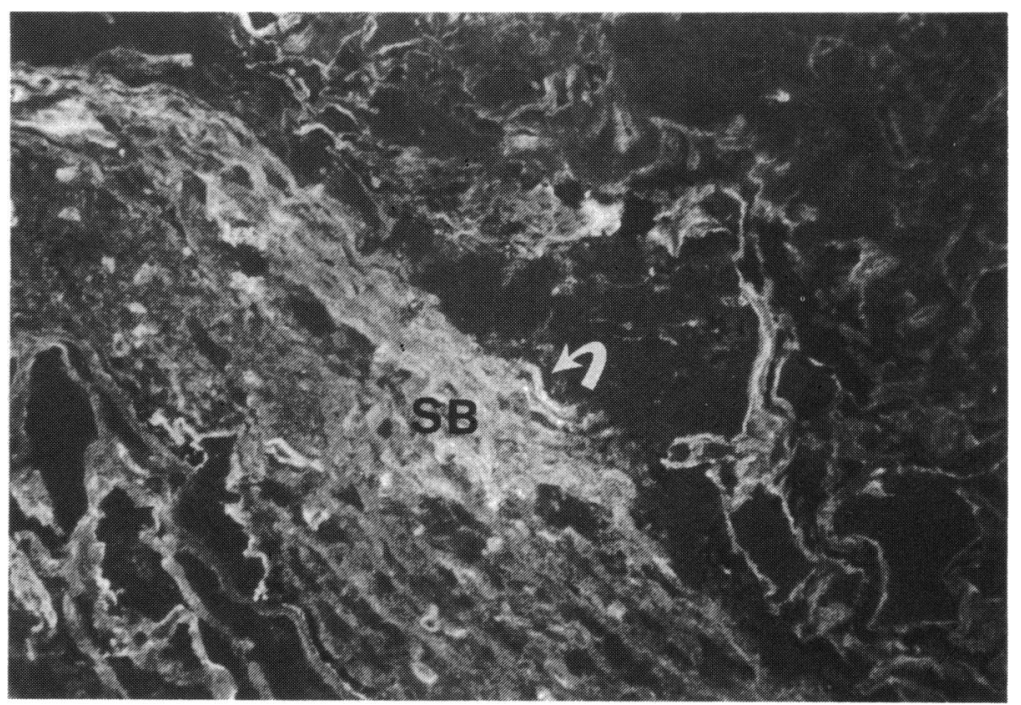


Table 1 Immunohistologic findings in pars planitis eye

\begin{tabular}{|c|c|c|c|c|}
\hline Antibody & Specificity & Snowbank & Pars plana & Iris/ciliary body \\
\hline Leu 2 & Suppressor/cytotoxic T cells ${ }^{15}$ & ND & + & + \\
\hline Leu 3 & Helper T cells ${ }^{15}$ & ND & +++ & ++ \\
\hline Leu 4 & Pan T cell ${ }^{16}$ & ++ & ++++ & ++ \\
\hline Leu 7 & Natural killer cells ${ }^{17}$ & - & - & - \\
\hline Leu 8 & Helper T cells ${ }^{15}$ & ND & +++ & ND \\
\hline Leu 10 & $\mathrm{HLA} \mathrm{DQ}^{18}$ & - & ++ & - \\
\hline Leu 14 & B cells ${ }^{19}$ & - & - & ++++ \\
\hline Leu 15 & Cytotoxic cells ${ }^{20}$ & - & - & - \\
\hline $\mathrm{OKM}_{1}$ & Monocytes/macrophages ${ }^{21}$ & - & - & - \\
\hline Anti-DR & HLA-DR ${ }^{22}$ & +++ & $+t+$ & +++ \\
\hline Anti-TAC & Interleukin 2 receptor ${ }^{23}$ & - & - & - \\
\hline Anti-S-Ag & S antigen ${ }^{24}$ & - & - & - \\
\hline Anti-Mu & Muller cells ${ }^{25}$ & ++ & & \\
\hline Anti-GFAP & Glial fibrillary acid protein ${ }^{26}$ & +++ & & \\
\hline Anti-coll I & Collagen Type $\mathrm{I}^{27}$ & - & - & - \\
\hline Anti-coll III & Collagen Type III $^{27}$ & - & - & - \\
\hline Anti-coll IV & Collagen Type IV ${ }^{27}$ & ++ & - & - \\
\hline Anti-laminin & Laminin $^{27}$ & $+t$ & - & - \\
\hline
\end{tabular}

free of inflammatory cells. There was no retinal vasculitis. No area of snowbanking was present.

\section{Discussion}

We report here the immunopathological features of an eye with pars planitis. The observation that snowbanking consists mainly of glial elements ${ }^{11}$ is confirmed by staining with anti-Müller cell antibody and GFAP. Müller cells proliferate in response to factors produced by activated lymphocytes, ${ }^{28}$ suggesting a means whereby the snowbank formation is stimulated by inflammation. In turn, Müller cells can express class II MHC molecules and present antigen to $\mathrm{T}$ cells, ${ }^{29}$ contributing to the inflammation themselves. Type IV collagen and laminin were the major collagen glycoproteins in this snowbank. They are formed by glial cells rather than fibroblasts, as are collagen types I and III. This suggests that the snowbank could be formed from the glial elements of the peripheral retina which was observed by electron microscopic studies in the case studied by Kenyon et al. " Among the various uveitis entities pars planitis appears to be unique in the propensity to stimulate a glial response of this nature, with the exception of the subretinal fibrosis and uveitis syndrome $\mathrm{e}^{30}$ and cyclitic membrane formation. ${ }^{31}$ These observations show evidence for a postinflammatory glial proliferation.

Anti-rod-cone (S antigen) antibody does not label the snowbank, suggesting that the photoreceptor cells did not contribute to its formation. This is in spite of the observation that one out of three patients with pars planitis have peripheral lymphocytes that respond to stimulation with $S$ antigen. ${ }^{32}$ In this case the patient did not respond with lymphocyte proliferation to $S$ antigen, however.
The $\mathrm{T}$ cell predominance in the pars plana shows that the inflammatory response in this case is possibly cell mediated. There were few $B$ cells posterior to the junction of the iris and ciliary body, where the pocket of $B$ cells and $T$ cells was found. There were not enough cells in the vitreous of our specimen to compare with the snowbank cellular makeup. Our patient, like other patients with pars planitis ${ }^{33}$ had normal peripheral $T$ cell counts. The high ratio of helper cell to suppressor cell in this eye parallels the finding of lymphoid accumulations in several systemic autoimmune disorders such as rheumatoid arthritis ${ }^{34}$ and chronic active hepatitis ${ }^{35}$ suggesting an active $T$ cell mediated process in the eye.

The eye studied represents an end stage state of disease. Any comparison with eyes that have pars planitis at earlier stages must be made with caution. The effects of the chronicity of the pathology and the effects of surgery must be considered. The eye studied had surgery eight months prior to enucleation, which might have led to some inflammation. A control eye with prior retinal detachment surgery was chosen to see if detachment surgery alone could produce this picture of inflammation. The absence of inflammation in the control eye indicates that longstanding retinal detachment after surgery does not always cause inflammation by itself.

There have been earlier reports of familial pars planitis. ${ }^{31213}$ In our study the brothers not only each have bilateral pars planitis, but also share the identical HLA antigens, HLA A2, A3; B7, B57; DR2, DR7. In the study by Augsburger et al. ${ }^{13}$ one of two families had three children with pars planitis sharing HLA A2, A11, B5, B40, and Cw3, while the unaffected siblings had different HLA combinations. In another family they studied there was no such 
HLA identity between siblings with disease. More data with larger pedigrees are required to establish the presence of a susceptibility gene or gene combination, as suggested by the one small family reported here. Attempts to study the population frequency of the various HLA antigens in pars planitis in the past have not shown a definite pattern. Ohno et al. showed a highly significant association between HLA-B27 and adult onset iridocyclitis, but not between any HLA antigen and chronic cyclitis (pars planitis)..$^{36}$

In summary, we report a case of pars planitis with positive family history. The ocular inflammatory process consists of glial elements with predominantly $T$ helper cell infiltrates.

The control eye was provided by Dr Stephen Ginsberg and Dr Garth Stevens. Very helpful secretarial assistance was provided by Ms Elayne Coggins.

\section{References}

1 Schepens CL. Examination of the ora serrata region: its clinical significance. ACTA 16 Concilium Ophthalmologicum Britannia. London: British Medical Association, 1950; 2: 1384-93.

2 Brockhurst RJ, Schepens CL, Okamura ID. Uveitis II. Peripheral uveitis: clinical description and differential diagnoses. Am J Ophthalmol 1960; 49: 1257-66.

3 Kimura SJ, Hogan MJ. Chronic cyclitis. Trans Am Ophthalmol Soc 1963; 61: 397-413.

4 Welch RB, Maumenee AE, Wahleu HE. Peripheral posterior segment inflammation, vitreous opacities, and edema of the posterior pole. Pars planitis. Arch Ophthalmol 1960; 64: 540-9.

5 Aaberg TM, Cesarz TJ, Flickinger RR. Treatment of pars planitis. I. Cryotherapy. Surv Ophthalmol 1977; 22: 120-5.

6 Schlaegel TF, Weber JC. Treatment of pars planitis. II. Corticosteroids. Surv Ophthalmol 1977; 22: 120-30.

7 Schlaegel TF. Ocular toxoplasmosis and pars planitis. New York: Grune and Stratton, 1978: 334-7.

8 Nussenblatt RB, Palestine AG, Chan C-C. Cyclosporine A therapy in the treatment of intraocular inflammatory disease resistant to systemic corticosteroids and cytotoxic agents. Am J Ophthalmol 1983; 96: 275-82.

9 Pederson JE, Kenyon KR, Green WR, Maumenee AE. Pathology of pars planitis. Am J Ophthalmol 1978; 86: 762-74.

10 Brockhurst RJ, Schepens CL, Okamura ID. Uveitis. 3 Peripheral uveitis. Pathogenesis, etiology, and treatment. Am J Ophthalmol 1961; 51: 19-25.

11 Kenyon KR, Pederson JE, Green WR, Maumenee AE. Fibroglial proliferation in pars planitis. Trans Ophthalmol Soc UK 1975; 95: 391-7.

12 Witmer MJ, Korrer G. Uveitis in Kindesalter. Ophthalmologica 1966; 152: 277-82.

13 Augsburger JJ, Annesley WHH, Sergott RC, Felberg NT, Bowman JH, Raymond LA. Familial pars planitis. Ann Ophthalmol 1981; 13: 553-7.

14 Hsu SM, Raine L, Fauger H. The use of avidin-biotin-peroxidase complex $(A B C)$ in immunoperoxidase technique: a comparison between $\mathrm{ABC}$ and unlabeled antibody (PAP) procedures. J Histochem Cytochem 1981; 29: 577-80.

15 Engleman EG, Benike CJ, Glickman E, Evans RL. Antibodies to membrane structures that distinguish suppressor/cytotoxic and helper T lymphocyte subpopulations block the mixed leukocyte reaction in man. $J$ Exp Med 1981; 154: 193-8.

16 Ledbetter JA, Evans RL, Lipinski M, Cunningham Rundles C, Good RA, Henzenberg LA. Evolutional conservation of surface molecules that distinguish $\mathrm{T}$ lymphocyte helper/inducer and cytotoxic/suppressor subpopulations in mouse and man. $J$ Exp Med 1981; 153: 310-23.

17 Abo T, Balch CM. A differentiation antigen of human NK and $\mathrm{K}$ cells identified by a monoclonal antibody (HNK-1). J Immunol 1981; 127: 1024-9.

18 Chen YX, Evans RL, Pollack MS, et al. Characterization and expression of the HLA-DC antigens defined by anti-Leu- 10 . Hum Immunol 1984; 10: 1221-35.

19 Schwanting R, Stein H, Wang CY. The monoclonal antibodies anti-S-HC $1-1$ and anti-S-HCl-3 allow the diagnoses of hairy cell leukemia. Blood 1985; 65: 974-83.

20 Landay A, Gantland L. Clement LT. Characterization of a phenotypically distinct subpopulation of Leu-2 cells which suppresses T-cell proliferative responses. J Immunol 1983; 131: 2757-61.

21 Breard J, Reinherz EL, Kung PC, et al. A monoclonal antibody reactive with human peripheral blood monocytes. $J$ Immunol 1980; 124: 1943-8.

22 Reinherz EL, Kung PC, Pesando JM, et al. la determinants on human $\mathrm{T}$ cell subsets defined by monoclonal antibody: activation stimuli required for expression. J Exp Med 1979; 150: 1472-82.

23 Uchiyama T, Broder S, Waldman TA. A monoclonal antibody (anti-Tac) reactive with activated and functionally mature human t-cells. I. Production of anti-Tac monoclonal antibody and distribution of Tac(+) cells. J Immunol 1981; 126: 1393-7.

24 Mirshahi M, Faure JP, Brisson P, Falcon J, Geurlotte J, Collin JP. S-antigen immunoreactivity in retinal rods and cones and pineal photosensitive cells. Biol Cell 1984; 52: 195-8.

25 Chan C-C, Rozenszajn LA, Nussenblatt RB, et al. Monoclonal antibodies to Müller's cells of the retina. Invest Ophthalmol Vis Sci 1984; 25: 1007-12

26 Eng LF, DeArmond SJ. Immunohistochemistry of the glial fibrillary acidic protein. In: Zimmerman HM, ed. Progress in neuropathology. New York: Raven Press 1983: 19-39.

27 Martin GR, Timpl R, Muller PK, Kuhn K. The genetically distinct collagens. Trends in Biochemical Sciences 1985; 10: 285-7.

28 Roberge FG, Caspi RR, Chan C-C, Kuwabara T, Nussenblatt RB. Long term culture of Muller cells from adult rats in the presence of activated lymphocytes/monocytes products. Curr Eye Res 1985; 4: 975-82.

29 Roberge FG, Caspi RR, Chan C-C, Nussenblatt RB. Antigen presentation by retinal glial cells. 4th International symposium on the immunology and immunopathology of the Eye. Italy, 1986 (in press).

30 Palestine AG, Nussenblatt RB, Chan C-C. Hooks JJ, Friedman L, Kuwabara T. Histopathology of the subretinal fibrosis and uveitis syndrome. Ophthalmology 1985; 92: 836-44.

31 Chan C-C, Fujikawa LS, Rodrigues MM, Stevens G, Nussenblatt RB. Immunohistochemistry and electron microscopy of cyclitic membrane. A case report. Arch Ophthalmol 1986; 104: 1040-5.

32 Nussenblatt RB, Gery I, Ballantine EJ. Cellular responsiveness of uveitis patients to retinal S-antigen. Am J Ophthalmol 1980; 89: 173-9.

33 Yokoyama MM, Matsui Y, Yamashiroya HM, et al. Humoral and cellular immunity studies in patients with Vogt-KoyanagiHarada syndrome and pars planitis. Invest Ophthalmol Vis $\mathbf{S} i$ 1981; 20: 364-70.

34 Janossy G, Duke O, Poulter LW, et al. Rheumatoid arthritis: a disease of T-lymphocyte/macrophage immunoregulation. Lancet 1981; ii: 839-42.

35 Si L, Whiteside TL, Schade RR, Van Thiel DH. Studies of lymphocyte subpopulations in the liver tissue and blood of patients with chronic active hepatitis (CAH). J Clin Immunol 1983; 3: 408-19.

36 Ohno S, Kimura SJ, O'Connor RG, Char DH. HLA antigens and uveitis. Br J Ophthalmol 1977; 61: 62-4.

Accepted for publication 4 December 1986. 